\title{
Interleukin (IL)-33 and the IL-1 Family of Cytokines-Regulators of Inflammation and Tissue Homeostasis
}

\author{
Ajithkumar Vasanthakumar ${ }^{1,2}$ and Axel Kallies ${ }^{1,2,3}$ \\ ${ }^{1}$ Department of Medical Biology, University of Melbourne, Melbourne, Victoria 3052, Australia \\ ${ }^{2}$ The Walter and Eliza Hall Institute of Medical Research, Melbourne, Victoria 3052, Australia \\ ${ }^{3}$ The Peter Doherty Institute for Infection and Immunity, University of Melbourne, Melbourne, \\ Victoria 3000, Australia \\ Correspondence: kallies@wehi.edu.au
}

Cytokines play an integral role in shaping innate and adaptive immune responses. Members of the interleukin (IL)-1 family regulate a plethora of immune-cell-mediated processes, which include pathogen defense and tissue homeostasis. Notably, the IL-1 family cytokine IL-33 promotes adaptive and innate type 2 immune responses, confers viral protection and facilitates glucose metabolism and tissue repair. At the cellular level, IL-33 stimulates differentiation, maintenance, and function of various immune cell types, including regulatory T cells, effector $\mathrm{CD}^{+}$and $\mathrm{CD} 8^{+} \mathrm{T}$ cells, macrophages, and type 2 innate lymphoid cells (ILC2s). Other IL- 1 family members, such as IL-1 $\beta$ and IL-18 promote type 1 responses, while IL-37 limits immune activation. Although IL-1 cytokines play critical roles in immunity and tissue repair, their deregulated expression is often linked to autoimmune and inflammatory diseases. Therefore, IL-1 cytokines are regulated tightly by posttranscriptional mechanisms and decoy receptors. In this review, we discuss the biology and function of IL-1 family cytokines, with a specific focus on regulation and function of IL-33 in immune and tissue homeostasis.

nterleukin (IL)-1 family cytokines are potent initiators and amplifiers of immune responses and inflammation. Because they are secreted by damaged cells and are crucial for eliciting inflammatory responses, these cytokines are also called "alarmins." Deregulated expression of IL1 family members aggravates inflammation, autoimmunity, and allergic responses. Consequently, IL-1 blockade is used for the treatment of a variety of inflammatory diseases, including rheumatoid arthritis, psoriasis, arthrosclerosis, ischemia, and reperfusion and graft rejection (Garlanda et al. 2013; Jesus and Goldbach-Man- sky 2014). However, IL-1 family cytokines also play critical roles in facilitating tissue repair and preserving homeostasis. Thus, expression of IL1 family members is tightly regulated at multiple levels, including transcriptional and posttranslational mechanisms as well as the expression of decoy and antagonist receptors (Garlanda et al. 2013). IL-1 family cytokines can also function as nuclear factors and influence gene expression by interacting with transcription factors or the chromatin (Martin and Martin 2016). IL-1 family members also act as RNA-splicing factors to regulate the expression of genes that are involved

Editors: Warren J. Leonard and Robert D. Schreiber

Additional Perspectives on Cytokines available at www.cshperspectives.org

Copyright (C) 2019 Cold Spring Harbor Laboratory Press; all rights reserved; doi: 10.1101/cshperspect.a028506

Cite this article as Cold Spring Harb Perspect Biol 2019;11:a028506 
in diverse physiological roles, which include survival and thermogenesis (Pollock et al. 2003; Odegaard et al. 2016).

IL-33 is a prominent member of the IL-1 family, which was discovered in 2003 (Baekkevold et al. 2003) after more than two decades of search to identify a ligand for the orphan IL-1 receptor ST2 (Tominaga 1989). IL-33 was first recognized for its critical role in the induction of allergic asthma by coordinating the expansion and function of adaptive and innate immune cells (Hardman and Ogg 2016). Consistent with this notion, genome-wide association studies (GWAS) have implicated polymorphisms in IL-33 or its receptor ST2 (IL1RL1) in a range of diseases that includes asthma, cardiovascular diseases, and allergy (Hardman and Ogg 2016). More recently, however, novel roles for IL-33 were uncovered that extend beyond immunity. For example, IL-33 was identified to play a prominent role in adipose tissue homeostasis, where it facilitates the expansion of anti-inflammatory immune cells, including type 2 innate lymphoid cells (ILC2)s and regulatory T (Treg) cells, thereby suppressing obesity-induced inflammation and preserving insulin sensitivity (Brestoff et al. 2015; Lee et al. 2015; Vasanthakumar et al. 2015). Similar functions in repair and maintenance of nonlymphoid tissues were also described for other tissues such as the colon or injured muscle tissue (Burzyn et al. 2013b; Schiering et al. 2014; Kuswanto et al. 2016). IL-33 therefore plays critical and context-specific roles in lymphoid and nonlymphoid tissues by preserving tissue homeostasis or mediating inflammation. This review focuses on the multifaceted functions of IL-33; however, we will also discuss the biology of other IL-1 family cytokines.

\section{SOURCES OF IL-33 AND OTHER IL-1 FAMILY CYTOKINES}

The IL-1 family consists of 11 members with diverse and complex functions (Garlanda et al. 2013). Most members of this family are expressed constitutively as full-length isoforms in a wide range of hematopoietic and nonhematopoietic cells, but are only processed and released by cells stimulated through Toll-like receptors
(TLRs) or by damaged cells undergoing necrosis (Sims and Smith 2010). IL-33 was first identified as a nuclear factor expressed in high endothelial venules of the human Peyer's patches, tonsils, and lymph nodes (Baekkevold et al. 2003). It was later found to be produced by endothelial and epithelial cells and by some hematopoietic cell types, including dendritic cells (Schmitz et al. 2005), mast cells (Hsu et al. 2010), and macrophages (Fock et al. 2013). IL-33 protein is constitutively expressed in astrocytes and oligodendrocytes within the central nervous system (CNS); however, its expression and secretion is elevated upon CNS injury (Yasuoka et al. 2011; Gadani et al. 2015). High expression of IL33 was also found in endothelial cells of various tissues, including the adipose tissue, liver, ovaries, vagina, skin, lung, stomach, and salivary gland (Villaret et al. 2010; Lopetuso et al. 2012; Pichery et al. 2012; Byers et al. 2013; Carlock et al. 2014). In steady state, IL-33 is found predominantly in the nucleus of these cells with no evidence of cytoplasmic localization. Inflammation induces IL-33 expression in epithelial cells, but only tissue damage is thought to result in efficient IL-33 release (Martin and Martin 2016). Similarly, expression of IL-33 is heightened in the liver during lipopolysaccharide (LPS)-induced endotoxin shock, and in the lung alveoli during papain-induced allergic airway inflammation (Pichery et al. 2012). A similar phenomenon was observed in colonic epithelium where IL-33 expression increased after inflammation and injury (Schiering et al. 2014) and in retinal Müller cells during macular degeneration (Xi et al. 2016). IL-33 can be detected in the serum of patients with inflammatory diseases or cancer and can potentially be used as a diagnostic and prognostic marker for a range of diseases, including hepatitis $\mathrm{B}$ infection (Wang et al. 2012), psoriasis (Mitsui et al. 2016), acute ischemic stroke (Qian et al. 2016), and non-small-cell lung cancer (Hu et al. 2013).

Similar to IL-33, other members of the IL-1 family are produced by a variety of hematopoietic and nonhematopoietic cells. Full-length IL$1 \alpha$ protein is expressed constitutively in healthy epithelial cells of the intestine, kidney, liver, endothelial cells, and astrocytes (Sims and Smith 
2010). Sterile inflammation caused by tissue injury facilitates the release of IL- $1 \alpha$, aiding the recruitment of macrophages to the injured site, which may augment tissue damage (Rider et al. 2011). In contrast, during programmed apoptosis, IL- $1 \alpha$ is retained in the nucleus to prevent tissue damage (Cohen et al. 2010). In macrophages, de novo synthesis of IL- $1 \alpha$ occurs after stimulation with LPS (Arango Duque and Descoteaux 2014). IL-1 $\beta$ is produced predominantly by cells of the hematopoietic compartment, including macrophages, blood monocytes, and dendritic cells. In contrast to IL- $1 \alpha$, which is largely constitutively expressed, transcription of $I l 1 b$ is induced by components of the complement system, tumor necrosis factor (TNF), TLR ligands, and IL-1 $\beta$ itself (Sims and Smith 2010). IL-18 is produced by two major immune cell populations, macrophages, and dendritic cells (Dinarello et al. 2013). However, stromal cells, including endothelial cells, keratinocytes, and intestinal epithelial cells constitutively express the IL-18 precursor (Dinarello et al. 2013). Similar to IL-1 $\beta$ and IL-33, mature IL-18 is released from tissues undergoing necrosis (Mommsen et al. 2009). IL-36 is expressed in several tissues, including skin, gut, lung, keratinocytes, and brain, and in some hematopoietic cells, including macrophages, neutrophils (Bozoyan et al. 2015), and T cells (Vigne et al. 2011). Similar to other IL-1 family members, IL-36 expression can be up-regulated by inflammatory stimuli, including LPS. In skin epithelial cells, IL-36 is upregulated during psoriasis, and in bronchial cells during viral or bacterial infection (Boutet et al. 2016). Unlike other IL-1 family members, IL-37 expression can be induced by the antiinflammatory cytokine transforming growth factor (TGF)- $\beta$ (Nold et al. 2010). However, in peripheral blood monocytic cells and dendritic cells, IL-37 expression was also elevated by stimulation through TLRs (Sharma et al. 2008; Nold et al. 2010). Expression of the little-known IL-38 cytokine is restricted to few tissue sites, including skin and the spleen (Lin et al. 2001). In summary, while IL-1 family cytokines are expressed by a wide variety of tissues, they are usually released only in response to "danger" signals.

\section{IL-33 AND T HELPER (Th)2 RESPONSES}

Extracellular pathogens such as helminths and nematodes induce a Th2-type inflammation mediated by the cytokines IL- 4 and IL-5. IL-33 was originally classified as a Th2 cytokine owing to its role in amplifying type 2 immune responses and exacerbating allergic asthma. This idea was supported by the finding that expression of IL-33 receptor ST2 appeared to be restricted to the Th2 lineage (Lohning et al. 1998). Indeed, IL-33 stimulation increases IL-5 and IL13 but not IL- 4 secretion by Th2 cells (Kurowska-Stolarska et al. 2008). In line with this finding, Th2 cells expressing ST2 secrete IL-5 and are highly pathogenic (Endo et al. 2015). Consistent with a central role in Th2 responses, ST2 was indispensable for Th2 responses in specific helminth infection models (Hoshino et al. 1999). Notably, IL-33 also acts as a chemoattractant for human Th2 cells (Komai-Koma et al. 2007).

In addition to Th2 cells, ILC2s play a key role in promoting airway inflammation. They express high amounts of ST2 and are exquisitely responsive to IL-33, which induces secretion of IL-5 and IL-13 (Moro et al. 2010; Neill et al. 2010). IL-33 administration expands the lung ILC2s, leading to airway hyperresponsiveness (Moro et al. 2010; Barlow et al. 2012). ROR $\alpha$ deficient mice, which lack ILC2, were unable to initiate Th2 responses when treated with papain (Halim et al. 2014). Notably, IL-33-expanded ILC2s also produce the tissue repair and growth factor amphiregulin (AREG), an epidermal growth factor (EGF) receptor ligand (Monticelli et al. 2011). IL-5 and IL-13, secreted by both Th2 cells and ILC2s, contribute to the recruitment of eosinophils, which amplifies allergic airway inflammation (Yamaguchi et al. 1988; Pope et al. 2001; Nussbaum et al. 2013). In allergic asthma, eosinophils are a major source of IL- 4 and mediate inflammation by releasing cytotoxic granules and lipid mediators that induce tissue damage and bronchoconstriction (Kita 2011). IL-33 contributes to this process not only by mediating the expansion of Th2 cells and ILC2s, but additionally it can promote the differentiation of eosinophils from $\mathrm{CD} 117^{+}$progenitors in an IL- 
A. Vasanthakumar and A. Kallies

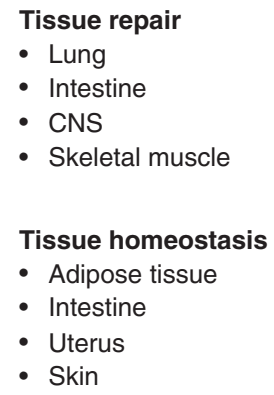

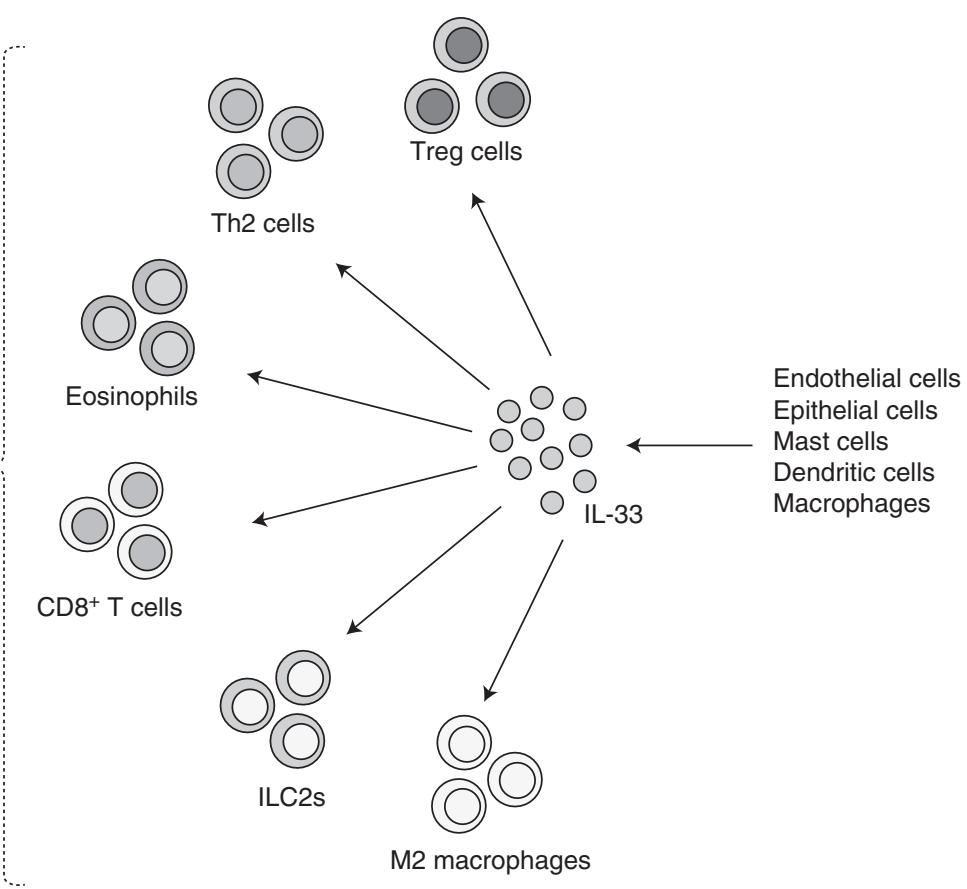

Figure 1. Illustration shows the diverse cellular sources of interleukin (IL)-33, sensing of IL-33 by adaptive and innate immune cells, and the plethora of immunological and nonimmunological functions regulated by IL-33 to preserve immune and tissue homeostasis. CNS, Central nervous system; Th, T helper; Treg, regulatory T cells; ILC2s, type 2 innate lymphoid cells.

5-dependent manner (Stolarski et al. 2010). Eosinophils in the airway express high levels of ST2 and respond to IL-33 secreted by lung epithelial cells (Kurowska-Stolarska et al. 2008). IL-33 not only promotes differentiation of eosinophils, but also improves their function by augmenting the expression of IL-13, IL-6, CCL-17, and TGF$\beta$ (Stolarski et al. 2010). IL-33 also induces the differentiation and expansion of alternatively activated M2 macrophages, which express the IL-4R, secrete CCL-24 and CCL-17 and cooperate with Th2 cells and eosinophils in airway inflammation (Kurowska-Stolarska et al. 2009). In agreement with its role in promoting and amplifying airway inflammation, mutations in Il33 and Il1rl1 (encoding ST2) are closely associated with increased asthma risk (Gudbjartsson et al. 2009; Moffatt et al. 2010). Taken together, IL-33 initiates and amplifies Th2 inflammation by promoting the differentiation, maintenance, and function of Th2 cells, ILC2s, eosinophils, and alveolar macrophages (Fig. 1; Table 1).

\section{IL-33 AND Th1 RESPONSES}

Intracellular pathogens, including bacteria and viruses, induce type 1 inflammation executed by $\mathrm{CD}^{+}$and $\mathrm{CD}^{+}{ }^{+}$cells, macrophages, and $\mathrm{B}$ cells. Recent studies have shown that IL-33 is also involved in the establishment of Th1 inflammation and cytotoxic T-cell responses. During lymphocytic choriomeningitis virus (LCMV) infection, Th1 cells were found to express ST2 in a T-bet- and signal transducers and activators of transcription (STAT)4-dependent manner (Baumann et al. 2015). ST2 expression in Th1 cells, however, was transient compared to the constitutive high levels observed in Th2 cells. ST2 contributed to the expansion of antigenspecific Th1 cells and promoted the expression of Th1 transcription factor T-bet (Baumann et al. 2015). Another study found that IL-33 induced Th1 cell differentiation by potentiating the activity of the Th1-polarizing cytokine IL12 ; however, IL-33 by itself was unable to pro- 
Table 1. Cytokine and receptor nomenclature of the interleukin (IL)-1 family and their functions mediated by immune cells.

\begin{tabular}{|c|c|c|c|c|}
\hline Cytokine & Receptor & Coreceptor & Immune cell target & Function \\
\hline IL-33 & ST2 & IL-1RAcP & $\begin{array}{l}\text { Th2 and Th1 cells, Treg cells, } \\
\text { macrophages, CD } 8^{+} \text {T cells, } \\
\text { eosinophils, ILC2s, NK cells, NKT } \\
\text { cells }\end{array}$ & $\begin{array}{l}\text { Type } 1 \text { and type } 2 \text { immunity, } \\
\text { maintenance of organismal } \\
\text { metabolism, thermogenesis, tissue } \\
\text { repair }\end{array}$ \\
\hline IL- $1 \alpha$ & $\begin{array}{l}\text { IL-1R1 } \\
\text { IL1-R2 }\end{array}$ & IL-1RAcP & Macrophages & Sterile inflammation \\
\hline IL-1 $\beta$ & $\begin{array}{l}\text { IL-1R1 } \\
\text { IL1-R2 }\end{array}$ & IL-1RAcP & $\begin{array}{l}\text { Th17 cells, Th1 cells, ILC1s, } \\
\text { regulatory B cells }\end{array}$ & $\begin{array}{l}\text { CNS inflammation, type } 1 \text { immunity, } \\
\text { gut homeostasis }\end{array}$ \\
\hline IL-18 & IL-18R $\alpha$ & IL-18R $\beta$ & $\begin{array}{l}\text { Th1 cells, } \mathrm{CD}^{+} \mathrm{T} \text { cells, NK cells, } \\
\text { ILC1s }\end{array}$ & Type 1 immunity \\
\hline $\begin{array}{l}\text { IL-36 } \alpha \text {, } \\
\quad \beta, \gamma\end{array}$ & IL-1Rrp2 & IL-1RAcP & $\mathrm{CD}^{+}{ }^{+} \mathrm{T}$ cells, NK cells, and $\gamma \delta \mathrm{T}$ cells & $\begin{array}{l}\text { Type } 1 \text { immunity, antitumor } \\
\text { immunity }\end{array}$ \\
\hline IL-37 & IL-18R $\alpha$ & & $\begin{array}{l}\text { Dendritic cells, macrophages, Treg } \\
\text { cells }\end{array}$ & Immune suppression \\
\hline IL-38 & IL-1Rrp2 & & $\mathrm{T}$ cells & Immune suppression \\
\hline IL-1RA & IL-1R1 & & Macrophages, dendritic cells, Th17 & Restrains inflammation \\
\hline IL-36RA & IL-1Rrp2 & & Unknown & Restrains inflammation \\
\hline
\end{tabular}

Th, T helper; Treg cell, regulatory T cell; ILC2, type 2 innate lymphoid cell; NK, natural killer; NKT cell, natural killer T cell; CNS, central nervous system.

mote Th1 differentiation (Komai-Koma et al. 2016). IL-33 was also found to induce ST2 expression in $\mathrm{CD}^{+} \mathrm{T}$ cells in vitro and augmented TCR-signaling-dependent interferon (IFN)- $\gamma$ production (Yang et al. 2011). In line with these findings, during infection with an acute strain of the LCMV, IL-33 promoted the clonal expansion and function of effector $\mathrm{CD} 8^{+} \mathrm{T}$ cells (Fig. 1) (Bonilla et al. 2012). IL-33 also expanded a population of $\mathrm{ST}_{2}{ }^{+}$natural killer T (NKT) cells and augmented TCR signaling and IL-12-dependent expression of IFN- $\gamma$ (Bourgeois et al. 2009). Similarly, IL-33 also induced IFN- $\gamma$ production in NK cells and promoted the NK cell response against murine cytomegalovirus $(\mathrm{Na}-$ bekura et al. 2015). Overall, these data suggest that IL-33 is a potent but context-specific amplifier of Th1 inflammation; however, its precise role needs to be further evaluated.

\section{IL-33 IN ORGANISMAL METABOLISM}

Visceral adipose tissue (VAT) is an important endocrine organ that secretes soluble factors such as leptin and adiponectin to regulate organismal metabolism (Coelho et al. 2013). VAT is also a reservoir for multiple pro- and antiinflammatory immune cells (Cipolletta et al. 2011; Wensveen et al. 2015). Obesity leads to the expansion of proinflammatory immune cells, which induce insulin resistance and, subsequently, type 2 diabetes (Cipolletta et al. 2011; Wensveen et al. 2015). Over the last few years, it has become apparent that IL-33 plays a central role in VAT homeostasis. IL-33 facilitates the differentiation and maintenance of Foxp ${ }^{+}$ Treg cells and ILC2s in the VAT, both of which play critical roles in limiting VAT inflammation and maintaining insulin sensitivity (Table 1 ) (Feuerer et al. 2009; Cipolletta et al. 2012; Brestoff et al. 2015; Vasanthakumar et al. 2015). Treg cells are a subset of $\mathrm{CD} 4^{+} \mathrm{T}$ cells that potently suppress autoreactive and inflammatory $\mathrm{T}$ cells. The majority of Treg cells develops in the thymus; however, they undergo further differentiation and diversification in the periphery, which allows them to acquire full suppressive function and the ability to enter nonlymphoid tissues, including the VAT (Burzyn et al. 2013a; Teh et al. 2015). VAT Treg cells co-opt the adipose tissue transcription factor PPAR- $\gamma$ for their differentiation and maintenance (Cipolletta et al. 
2012). While development and survival of Treg cells in most tissues is strictly dependent on IL-2 (Liston and Gray 2014), VAT-resident Treg cells in addition require IL-33 for their survival and maintenance (Vasanthakumar et al. 2015). VAT Treg cell numbers significantly decrease in the absence of IL-33 signaling. In vitro, IL-33 facilitated population expansion of VAT Treg cells even in the absence of IL-2 or TCR signaling (Vasanthakumar et al. 2015). IL-33 expression in the adipose tissue increased with age, which also correlates with an increase in VAT Treg cells, suggesting that IL-33 is the rate-limiting cytokine for Treg-cell expansion in the adipose tissue. In keeping with this notion, administration of IL-33 expanded Treg cells specifically in the adipose tissue (Kolodin et al. 2015; Molofsky et al. 2015; Vasanthakumar et al. 2015). Obesity leads to the decline of VAT Treg cell numbers, which coincides with exacerbation of inflammation in the VAT and development of insulin resistance (Fig. 1) (Feuerer et al. 2009; Vasanthakumar et al. 2015). When administered to obese mice, IL-33 rescued Treg cell numbers in the VAT, which coincided with suppression of inflammation and improved glucose tolerance (Han et al. 2015; Vasanthakumar et al. 2015). Besides facilitating survival and proliferation, IL-33 also enhances the expression of GATA3 and Foxp3 in VAT Treg cells, and preserves expression of PPAR- $\gamma$, suggesting a pivotal role for IL-33 in preserving VAT Treg cell function and phenotype (Vasanthakumar et al. 2015).

IL-33 is also a critical growth factor for VAT ILC2s, which promote the conversion of white adipose tissue to brown adipose tissue (BAT) (Brestoff et al. 2015; Lee et al. 2015). BAT is critically important for thermogenesis of newborns but also contributes to weight loss as it generates heat from chemical energy (calories). ILC2-derived methionine-enkephalin peptides induce the expression of brown adipocyte factor uncoupling protein-1 (UCP-1), required for thermogenesis (Brestoff et al. 2015). It has also been proposed that ILC2s were involved in mediating the IL-33-dependent VAT Treg cell expansion, as VAT Treg cells from IL-5-deficient mice, which lacked ILC2s, failed to expand upon
IL-33 treatment (Molofsky et al. 2015). However, such a mechanism has not yet been supported by additional studies. IL-33 also directly acted on adipose tissue to induce the expression of UCP-1 by an unconventional mechanism as discussed later (Odegaard et al. 2016). Thus, while it is clear that IL-33 plays a central role in maintaining adipose homeostasis, precisely how IL-33-responsive cells and IL-33-dependent mechanisms cooperate in the adipose to maintain tissue health remains to be elucidated. Of note, IL-18 also plays a protective role in obesity (Lee et al. 2016; Murphy et al. 2016), while IL-1 $\beta$ drives adipose tissue inflammation and insulin resistance (Lee et al. 2016).

\section{IL-33 IN TISSUE HOMEOSTASIS AND REPAIR}

As outlined earlier, IL-33 is released predominantly by inflamed or injured tissue. Remarkably however, IL-33 is also involved in tissue repair, a mechanism that is likely to have evolved as a feedback to restrain tissue damage. IL-33dependent Treg-cell-mediated tissue repair has been demonstrated in skeletal muscle and the lung (Fig. 1). Skeletal muscle regeneration critically depends on a self-renewing population of cells called satellite cells. Upon injury, satellite cells proliferate and differentiate into new myofibers or fuse to existing ones and promote regeneration. While inflammatory $\mathrm{CD}^{+}$and $\mathrm{CD}^{+} \mathrm{T}$ cells impede this process (Tidball and Villalta 2010), IL-33-dependent Treg cells maintain an environment conducive for satellite cell differentiation and muscle regeneration (Burzyn et al. 2013b). Treg cells that reside and expand in the muscle after injury critically depend on IL-33 (Kuswanto et al. 2016). Similar to the injured muscle, IL-33-dependent Treg cells play an important role in restraining inflammation in the gastrointestinal tract (Schiering et al. 2014). Consistent with this finding, Treg cells deficient for ST2 could not control experimental colitis. IL-23, a cytokine known to drive intestinal inflammation and inflammatory bowel disease, inhibited the function of IL-33 (Schiering et al. 2014).

Finally, IL-33 has been shown to induce expression of AREG in Treg cells. This function 
was shown to play a role in Treg-cell-mediated lung tissue repair after influenza virus infection. Lung epithelial cell-derived IL-33 induced upregulation of AREG in lung-resident Treg cells, which facilitated repair of damaged lung epithelium and improved lung function after resolution of the infection (Fig. 1) (Arpaia et al. 2015). AREG is also highly expressed in Treg cells in the adipose tissue (Vasanthakumar et al. 2015), suggesting that tissue repair is a common IL-33induced mechanism of action for Treg cells residing in nonlymphoid tissues. Indeed, IL-33 also induces AREG expression in ILC2s to promote tissue repair in the lung and intestinal epithelia (Monticelli et al. 2011, 2015). Treatment of mice with recombinant IL-33 increased the expression of tight junction proteins claudin 1 and mucin and improved intestinal integrity, thereby preserving barrier function (Monticelli et al. 2015). IL-33 also plays an important role in limiting brain tissue damage. Upon brain injury, damaged oligodendrocytes release IL-33, which acts on microglial cells and astrocytes to secrete chemokines and cytokines to attract neuroprotective M2 macrophages that facilitate neural tissue repair (Gadani et al. 2015). Similarly, ILC2s that reside in the meninges are activated by IL-33 secreted upon CNS injury and contribute to limiting CNS injury (Gadani et al. 2017). Finally, IL-33 has also been shown to induce the expansion of IL-10-producing B cells, thereby limiting inflammation in the intestine and protecting from inflammatory bowel disease (Sattler et al. 2014).

Inflammatory mediators within the tumor microenvironment can either promote an antitumor immune response or support tumor pathogenesis. In keeping with this notion, IL33 plays a context-dependent role in tumor biology where it can be protective or deleterious. For example, IL-33 facilitates the expansion of NK cells and cytotoxic CD ${ }^{+} \mathrm{T}$ cells to promote tumor eradication (Gao et al. 2015). On the other hand, IL-33 augments tumor growth by promoting colorectal cancer cell stemness (Fang et al. 2017) and metastasis in lung cancer (Wang et al. 2016a). The multifaceted role of IL-33 in the tumor environment was reviewed in more detail recently (Wasmer and Krebs
2016). Thus, while IL-33 maintains tissue homeostasis by augmenting population expansion and function of immune cells that facilitate tissue repair, it can also drive tumor growth (Fig. 1; Table 1).

\section{IMMUNE REGULATION BY OTHER IL-1 FAMILY MEMBERS}

In addition to IL-33, other IL-1 family cytokines play critical roles in the differentiation and function of multiple immune cells. IL-18 was originally identified as a costimulator of IFN- $\gamma$ production and subsequently established to contribute to Th1 differentiation (Yoshimoto et al. 1998). IL-18 was also required for the efficient production of IFN- $\gamma$ and TNF in antigen-specific $\mathrm{CD}^{+} \mathrm{T}$ cells, suggesting a prominent role for IL-18 in viral defense (Denton et al. 2007). Similarly, IL-18 promotes IFN- $\gamma$ production in NK cells and ILC1 (Table 1) (Chaix et al. 2008; Maloy and Uhlig 2013).

IL-1 $\beta$ promotes the differentiation of IL-17producing Th17 cells and $\gamma \delta$ T cells in vivo and have been implicated in autoimmune and inflammatory diseases that affect the CNS (Chung et al. 2009; Sutton et al. 2009). IL-6 induced IL1R1 expression on $\mathrm{CD} 4^{+} \mathrm{T}$ cells, thereby facilitating Th17 differentiation and induction of experimental autoimmune encephalomyelitis (Chung et al. 2009). Notably, Th17 cells themselves are equipped with NLRP3 and caspase-8, allowing for the secretion of bioactive IL- $1 \beta$, creating an autocrine loop that facilitates differentiation of Th17 cells (Martin et al. 2016). IL-1 $\beta$ also contributes to Th1 inflammation and cytotoxic T-cell differentiation by activating dendritic cells to produce IL-12 (Wesa and Galy 2001). Interestingly, IL-1 $\beta$ cooperates with IL33 in ILC2 biology. While IL-33 is critical for ILC2 cell differentiation, IL- $1 \beta$ is required for their activation. IL-1 $\beta$ also induces the expression of IL-12 receptor, which facilitates T-bet expression and transdifferentiation to ILC1 lineage cells (Ohne et al. 2016). Finally, gut microbiota-induced IL- $1 \beta$ is required for the differentiation of regulatory B cells, which contribute to immune homeostasis by producing the anti-inflammatory cytokine IL-10 (Rosser et al. 2014). 
A. Vasanthakumar and A. Kallies

Several lines of evidence suggest that IL- $1 \alpha$ and IL-1 $\beta$ promote tumorigenesis by inducing the expression of growth factors that facilitate tumor growth and metastasis. IL-1 induces the expression of several tumorigenic and metastatic mediators, such as matrix metalloproteinases (MMPs), vascular endothelial growth factor (VEGF), IL-8, IL-6, TNF, and TGF- $\beta$. Tumor tissue-derived IL- $1 \beta$ itself attracts immune cells, including macrophages and neutrophils, which further produce IL-1 $\beta$ to promote angiogenic response, tumor invasiveness, and metastasis (Apte et al. 2006; Perrier et al. 2009; Voronov

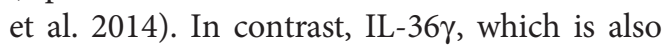
highly expressed in the tumor environment, plays a protective role in cancer by polarizing $\mathrm{CD} 8^{+} \mathrm{T}$ cells, NK cells, and $\gamma \delta \mathrm{T}$ cells to produce IFN- $\gamma$ and establishes a conducive setting for tumor eradication (Wang et al. 2015). Th1 cells have also been shown to express IL-36R, signaling through which synergized with IL-12 in Th1 differentiation in vivo (Vigne et al. 2012).

The anti-inflammatory cytokine of the IL-1 family, IL-37, plays a role in restraining activation of antigen-specific $\mathrm{T}$ cells by suppressing dendritic cell activation and limiting the expression of proinflammatory cytokines IL-1 $\beta$, IL-6, and IL-12 (Luo et al. 2014). IL-37 also repressed the expression of IL- 6 in LPS-induced macrophages, suggesting its role in dampening innate immune responses (Li et al. 2015). Finally, IL-37 promoted the suppressive properties of Treg cells by inducing up-regulation of IL-10, TGF$\beta$, and CTLA-4 (Wang et al. 2016b). Thus, IL-1 cytokines play diverse roles in infection autoimmunity and cancer.

\section{REGULATION OF EXPRESSION OF ACTIVE IL-33 AND OTHER IL-1 FAMILY CYTOKINES}

Production of IL-1 family members is tightly regulated at several levels. Notably, all IL-1 family members with the exception of IL-1 receptor antagonist (IL-1Ra) are translated without a signal peptide that would be required for active secretion via the endoplasmic reticulum and Golgi apparatus (Sims and Smith 2010; Afonina et al. 2015). Therefore, they need to be cleaved by caspases and proteases to release bioactive forms (Garlanda et al. 2013). For example, IL$1 \beta$ is secreted as a pro-IL- $1 \beta$, which is cleaved by caspase- 1 to release the bioactive IL- $1 \beta$ into circulation. While most immune cells express caspase-1, its activity is regulated by the inflammasome NLRP3. Neutrophil-secreted enzymes elastase and proteinase- 3 also cleave pro-IL- $1 \beta$ efficiently to generate the bioactive forms. In contrast, the IL- $1 \alpha$ precursor, which is released upon necrosis of source tissues, is readily available for the induction of inflammation, as it can activate signaling directly by binding to its receptor.

Similar to IL-1 $\beta$, IL-18 is translated as a 24 $\mathrm{kDa}$ protein, which then is cleaved by NLRP3activated caspase- 1 to become $17-\mathrm{kDa}$ active IL18. Thus, NLRP1-deficient mice also have reduced amounts of active IL-18, manifesting in spontaneous obesity (Murphy et al. 2016). ProIL-18 can be also cleaved by neutrophil-derived proteases and proteinase- 3 to generate the active form. The biological activity of IL-36 also requires posttranslational processing (Towne et al. 2011); however, precisely how pro-IL-36 is cleaved is unclear. Similarly, the mechanisms underlying IL-37 processing are unknown, although they are likely to involve caspase-1 ( $\mathrm{Li}$ et al. 2015).

IL-33, unlike most other members of the family, is released by necrotic cells as a $29-\mathrm{kDa}$ full-length protein that has bioactivity and does not require proteolytic processing (Martin and Martin 2016). Although originally believed to be processed by caspase-1, later studies revealed caspase-1 to be redundant for IL-33 activity (Talabot-Ayer et al. 2009). In contrast, proteases secreted by neutrophils, macrophages, and mast cells cleave the amino-terminal end of human IL-33, resulting in a 10-fold increase in activity (Lefrancais et al. 2012). On the other hand, caspase- 3 and -7 released by apoptotic cells can effectively cleave and inactivate IL-33. Thus, the expression of the active forms of IL-1 family cytokines is controlled by multiple posttranslational mechanisms that have evolved to balance the fine line between the beneficial and detrimental functions of the members of this cytokine family. 


\section{REGULATION OF IL-33 AND IL-1 FAMILY SIGNALING}

Most members of the IL-1 family signal by binding to heterodimeric receptors. IL-33, IL-1 $\alpha$, IL$1 \beta$, and IL-36 utilize a common receptor chain called IL-1RAcP. IL- $1 \alpha$, IL- $1 \beta$, and IL-1RA share yet another common receptor chain, IL-1R1. In contrast, ST2 is exclusively used by IL-33, while IL-1Rrp2 is specific to IL-36. IL-36RA is an IL36R antagonist that has more than $50 \%$ similarity to IL-1RA. IL- $1 \alpha$ and IL- $1 \beta$ can also signal by binding to IL-1R2. IL-18 and IL-37 bind and signal through a heterodimeric receptor composed of IL-18R $\alpha$ and IL-18R $\beta$ (Fig. 2; Table 1) (Garlanda et al. 2013). Despite the diversity in receptor recognition, all IL-1 family receptors possess a cytoplasmic Toll-IL-1R (TIR) domain and initiate a common signaling cascade, which is similar to TLRs and requires the adaptor Myd88 (O’Neill 2000). Signaling downstream of Myd88 involves IRAKs, TRAF6, and TAK1, leading to the activation of Janus kinase (JNK), extracellular signal-regulated kinase (ERK), and mitogen-activated protein kinase (MAPK) pathways. Eventually, transcription factors, including RelA/p65 (nuclear factor [NF]- $\kappa \mathrm{B}$ ) and c-Jun establish the transcriptional program activated by IL-1 family members (O’Neill and Greene 1998).
Proximal IL-1 family signaling is regulated tightly by decoy and antagonistic receptors (Sims and Smith 2010; Garlanda et al. 2013). For example, the IL-33 receptor is generated in two distinct forms that differ functionally: membrane-bound ST2 that allows functional IL-33 signaling and a shorter soluble form that sequesters available IL-33 (Yanagisawa et al. 1993; Garlanda et al. 2013; Martin and Martin 2016). Notably, increased soluble ST2 is a prognostic marker for several inflammatory diseases (Kim et al. 2015). Similarly, the soluble receptor isoform of IL-1R2 can bind to IL-1 $\beta$ extracellularly and render it unavailable for signaling. IL$1 \mathrm{R}$ signaling is also inhibited by the IL-1R antagonist, IL-1RA, which competes with IL$1 \beta$ for IL-1R1 receptor binding (Aksentijevich et al. 2009). Furthermore, soluble IL-1R2 and IL-1RAcP can also bind to pro-IL- $1 \beta$ efficiently and prevent its proteolytic processing. Similar mechanisms exist for other IL-1-like cytokines, for example, for IL-36, through expression of an antagonist receptor for IL-36, and for IL-18 through the expression of IL-18-binding protein (IL-18BP), which prevents IL-18 interaction with the receptor (Fig. 2; Table 1) (Sims and Smith 2010; Garlanda et al. 2013).

In addition to the above-described mechanisms that control the availability of IL-1-like

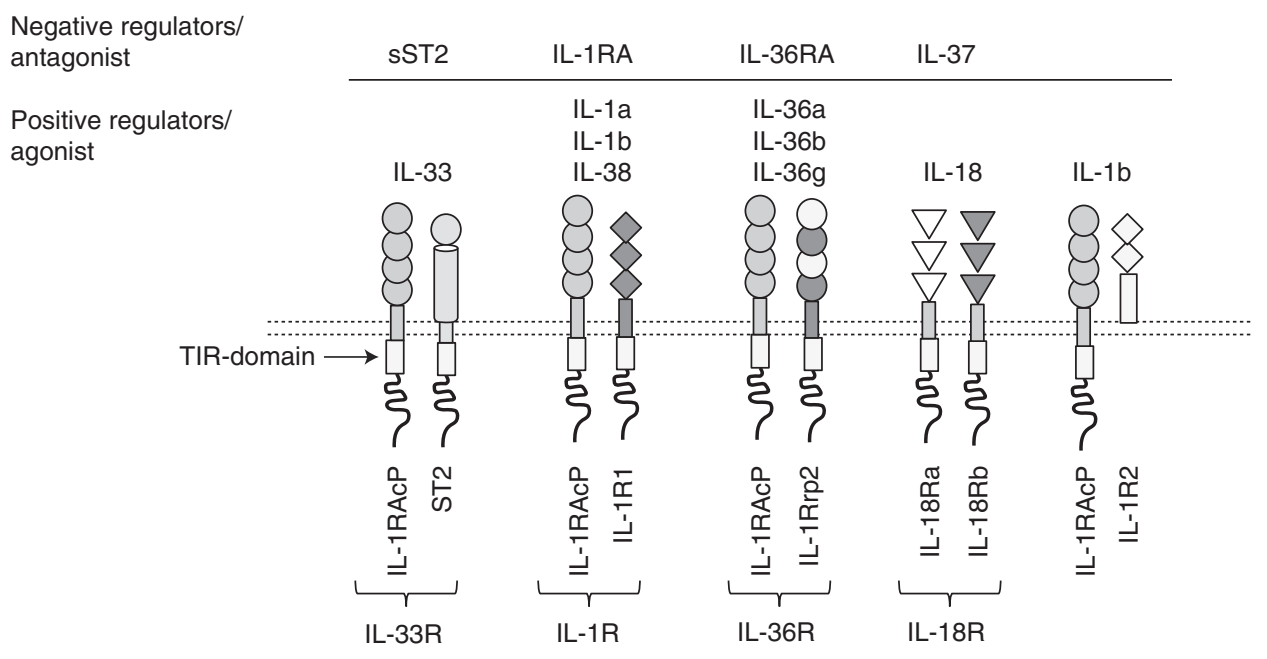

Figure 2. A schematic representation of interleukin (IL)-1 family receptors, coreceptors, ligands, and negative regulators. TIR, Toll-IL-1R. 
cytokines, the expression of some receptors is tightly governed by transcriptional mechanisms. This is particularly well known for ST2, the expression of which is controlled by the Th2 lineage-determining transcription factor Gata3 (Hayakawa et al. 2005). Similarly, ST2 expression in ILC2s (Hoyler et al. 2012; Mjosberg et al. 2012) and colonic Treg cells (Schiering et al. 2014) is regulated by Gata3. In contrast, Th1 cells expressed ST2 in a T-bet- and STAT4-dependent manner (Baumann et al. 2015). ST2 expression on Treg cells also required the TCR signaling-induced transcription factor IRF4 and its binding partner BATF (Vasanthakumar et al. 2015). A recent study has shown that PPAR- $\gamma$ is required for efficient ST2 expression on Th2 cells (Chen et al. 2017). It remains to be seen whether PPAR- $\gamma$ contributes to regulation of ST2 expression in other cell types.

\section{NUCLEAR FUNCTIONS OF IL-33, IL- $1 \alpha$, AND IL-37}

Unlike other cytokines, some IL-1 family members are known to have nuclear functions. IL-33, IL-1 $\alpha$, and IL-37 possess a nuclear localization sequence (NLS) that facilitates nuclear entry. IL33 also possesses an amino-terminal homeodomain like helix-turn-helix (HTH) DNA-binding domain (Carriere et al. 2007). Nuclear IL-33 can act both as a transcriptional activator and repressor in a context-specific manner. It can interact with histone $\mathrm{H} 2 \mathrm{~A}$ and $\mathrm{H} 2 \mathrm{~B}$ and regulate chromatin architecture and partner with the methyltransferase SUV39H1 to facilitate repression of genes (Carriere et al. 2007). Furthermore, IL-33 can cooperate with NF- $\kappa \mathrm{B}$ transcription factors p65/RelA and p50 and sequester them to the cytoplasm, thereby, preventing the expression of inflammatory genes (Ali et al. 2011). Although not a nuclear function, a recent study has also shown that intracellular IL-33 can regulate the splicing of uncoupling protein-1 (UCP-1) gene in adipocytes, thereby regulating thermogenesis and brown fat differentiation (Odegaard et al. 2016). Similar to IL-33, IL-1o can also translocate to the nucleus and activates transcription by interacting with chromatin (Garlanda et al. 2013). The range of functions regulated by nuclear IL- $1 \alpha$ includes proliferation, cell migration, apoptosis, and expression of cytokines, including IL-18 and TNF (Garlanda et al. 2013; van de Veerdonk and Netea 2013). Nuclear IL-1 $\alpha$ also interacts with NF- $\kappa B$ transcription factors to regulate gene expression and, similar to IL-33, facilitates the splicing of prosurvival molecule Bcl-xL (Pollock et al. 2003). Finally, IL-37 was shown to translocate to the nucleus and to repress the expression of inflammatory genes in LPS-treated macrophages (Sharma et al. 2008).

\section{CONCLUDING REMARKS}

IL-1 has long been known to play a central role in inflammation. More recently, IL-33 has emerged as another crucial regulator of immunity and tissue homeostasis (Fig. 1). However, while substantial advances were made over the last decade, there are many aspects of the biology of IL-1 family cytokines that remain unexplored. Processing of the procytokine forms into biologically active forms is a key and the foremost regulatory mechanism in IL-1 biology. Yet, the precise mechanism by which IL-33 is cleaved or the exact function of long versus short forms of IL-33 in immunity and inflammation are still a matter of intense debate. It is also incompletely known how specificity of signaling is achieved by members of the IL-1 cytokine family, given that the receptor chains are shared by many of the IL-1-like cytokines. For example, it is unclear whether ST2 or IL-1R compete for IL$1 \mathrm{RAcP}$ or interact with different affinities. In such a scenario, ST2 or IL-1R may sequester IL-1RAcP and thereby limit signaling through the other receptor. This may be critical when designing blocking antibodies for a particular cytokine as such antibodies may affect the activity of other cytokines that share the receptor chain. Similarly, while it is clear that soluble ST2 can limit the signaling of IL-33, it is unknown how the expression of the soluble and membrane-bound forms of ST2 is regulated. Importantly, although IL-33 is localized in the nucleus, its role in transcription has not been studied fully. It is also unclear whether the IL33 released extracellularly by necrotic or in- 
flamed tissue can act as a transcription factor in the target cell. Given the considerable "resource sharing" between IL-1 family members, which share molecules that activate them as well as receptors and signaling components, fully understanding the biology of IL-1 family cytokines, will be essential to exploit their therapeutic potential.

\section{ACKNOWLEDGMENTS}

We thank the members of the Kallies Laboratory for discussion. This work is supported by a Senior Medical Research Fellowship from the Sylvia and Charles Viertel Foundation (to A.K.).

\section{REFERENCES}

Afonina IS, Muller C, Martin SJ, Beyaert R. 2015. Proteolytic processing of interleukin-1 family cytokines: Variations on a common theme. Immunity 42: 991-1004.

Aksentijevich I, Masters SL, Ferguson PJ, Dancey P, Frenkel J, van Royen-Kerkhoff A, Laxer R, Tedgard U, Cowen EW, Pham TH, et al. 2009. An autoinflammatory disease with deficiency of the interleukin-1-receptor antagonist. $N$ Engl J Med 360: 2426-2437.

Ali S, Mohs A, Thomas M, Klare J, Ross R, Schmitz ML, Martin MU. 2011. The dual function cytokine IL-33 interacts with the transcription factor NF- $\mathrm{KB}$ to dampen NF- $\kappa \mathrm{B}-$ stimulated gene transcription. J Immunol 187: 1609-1616.

Apte RN, Dotan S, Elkabets M, White MR, Reich E, Carmi Y, Song X, Dvozkin T, Krelin Y, Voronov E. 2006. The involvement of IL-1 in tumorigenesis, tumor invasiveness, metastasis and tumor-host interactions. Cancer Metastasis Rev 25: 387-408.

Arango Duque G, Descoteaux A. 2014. Macrophage cytokines: Involvement in immunity and infectious diseases. Front Immunol 5: 491

Arpaia N, Green JA, Moltedo B, Arvey A, Hemmers S, Yuan S, Treuting PM, Rudensky AY. 2015. A distinct function of regulatory T cells in tissue protection. Cell 162: 10781089.

Baekkevold ES, Roussigne M, Yamanaka T, Johansen FE, Jahnsen FL, Amalric F, Brandtzaeg P, Erard M, Haraldsen G, Girard JP. 2003. Molecular characterization of NF$\mathrm{HEV}$, a nuclear factor preferentially expressed in human high endothelial venules. Am J Pathol 163: 69-79.

Barlow JL, Bellosi A, Hardman CS, Drynan LF, Wong SH, Cruickshank JP, McKenzie AN. 2012. Innate IL-13-producing nuocytes arise during allergic lung inflammation and contribute to airways hyperreactivity. J Allergy Clin Immunol 129: 191-198, e191-194.

Baumann C, Bonilla WV, Frohlich A, Helmstetter C, Peine M, Hegazy AN, Pinschewer DD, Lohning M. 2015. T-betand STAT4-dependent IL-33 receptor expression directly promotes antiviral Th1 cell responses. Proc Natl Acad Sci 112: $4056-4061$.

Bonilla WV, Frohlich A, Senn K, Kallert S, Fernandez M, Johnson S, Kreutzfeldt M, Hegazy AN, Schrick C, Fallon PG, et al. 2012. The alarmin interleukin-33 drives protective antiviral $\mathrm{CD}^{+} \mathrm{T}$ cell responses. Science 335: 984-989.

Bourgeois E, Van LP, Samson M, Diem S, Barra A, Roga S, Gombert JM, Schneider E, Dy M, Gourdy P, et al. 2009. The pro-Th 2 cytokine IL-33 directly interacts with invariant NKT and NK cells to induce IFN- $\gamma$ production. Eur J Immunol 39: 1046-1055.

Boutet MA, Bart G, Penhoat M, Amiaud J, Brulin B, Charrier C, Morel F, Lecron JC, Rolli-Derkinderen M, Bourreille A, et al. 2016. Distinct expression of interleukin (IL)-36 $\alpha, \beta$ and $\gamma$, their antagonist IL-36Ra and IL-38 in psoriasis, rheumatoid arthritis and Crohn's disease. Clin Exp Immunol 184: 159-173.

Bozoyan L, Dumas A, Patenaude A, Vallieres L. 2015. Inter-

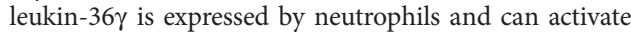
microglia, but has no role in experimental autoimmune encephalomyelitis. J Neuroinflammation 12: 173.

Brestoff JR, Kim BS, Saenz SA, Stine RR, Monticelli LA, Sonnenberg GF, Thome JJ, Farber DL, Lutfy K, Seale P et al. 2015. Group 2 innate lymphoid cells promote beiging of white adipose tissue and limit obesity. Nature 519: 242-246.

Burzyn D, Benoist C, Mathis D. 2013a. Regulatory T cells in nonlymphoid tissues. Nat Immunol 14: 1007-1013.

Burzyn D, Kuswanto W, Kolodin D, Shadrach JL, Cerletti M, Jang Y, Sefik E, Tan TG, Wagers AJ, Benoist C, et al. 2013b. A special population of regulatory T cells potentiates muscle repair. Cell 155: 1282-1295.

Byers DE, Alexander-Brett J, Patel AC, Agapov E, Dang-Vu G, Jin X, Wu K, You Y, Alevy Y, Girard JP, et al. 2013. Long-term IL-33-producing epithelial progenitor cells in chronic obstructive lung disease. J Clin Invest 123: 39673982.

Carlock CI, Wu J, Zhou C, Tatum K, Adams HP, Tan F, Lou Y. 2014. Unique temporal and spatial expression patterns of IL-33 in ovaries during ovulation and estrous cycle are associated with ovarian tissue homeostasis. J Immunol 193: 161-169.

Carriere V, Roussel L, Ortega N, Lacorre DA, Americh L, Aguilar L, Bouche G, Girard JP. 2007. IL-33, the IL-1-like cytokine ligand for ST2 receptor, is a chromatin-associated nuclear factor in vivo. Proc Natl Acad Sci 104: 282 287.

Chaix J, Tessmer MS, Hoebe K, Fuseri N, Ryffel B, Dalod M, Alexopoulou L, Beutler B, Brossay L, Vivier E, et al. 2008. Cutting edge: Priming of NK cells by IL-18. J Immunol 181: 1627-1631.

Chen T, Tibbitt CA, Feng X, Stark JM, Rohrbeck L, Rausch L, Sedimbi SK, Karlsson MCI, Lambrecht BN, Karlsson Hedestam GB, et al. 2017. PPAR- $\gamma$ promotes type 2 immune responses in allergy and nematode infection. Sci Immunol 2: aal5196.

Chung Y, Chang SH, Martinez GJ, Yang XO, Nurieva R, Kang HS, Ma L, Watowich SS, Jetten AM, Tian Q, et al. 2009. Critical regulation of early Th17 cell differentiation by interleukin-1 signaling. Immunity 30: 576-587.

Cipolletta D, Kolodin D, Benoist C, Mathis D. 2011. Tissular Tregs: A unique population of adipose-tissue-resident 
Foxp $3^{+} \mathrm{CD} 4^{+} \mathrm{T}$ cells that impacts organismal metabolism. Semin Immunol 23: 431-437.

Cipolletta D, Feuerer M, Li A, Kamei N, Lee J, Shoelson SE, Benoist C, Mathis D. 2012. PPAR- $\gamma$ is a major driver of the accumulation and phenotype of adipose tissue Treg cells. Nature 486: 549-553.

Coelho M, Oliveira T, Fernandes R. 2013. Biochemistry of adipose tissue: An endocrine organ. Arch Med Sci 9: 191200.

Cohen I, Rider P, Carmi Y, Braiman A, Dotan S, White MR, Voronov E, Martin MU, Dinarello CA, Apte RN. 2010. Differential release of chromatin-bound IL- $1 \alpha$ discriminates between necrotic and apoptotic cell death by the ability to induce sterile inflammation. Proc Natl Acad Sci 107: 2574-2579.

Denton AE, Doherty PC, Turner SJ, La Gruta NL. 2007. IL18 , but not IL-12, is required for optimal cytokine production by influenza virus-specific $\mathrm{CD}^{+}{ }^{+} \mathrm{T}$ cells. Eur $\mathrm{J}$ Immunol 37: 368-375.

Dinarello CA, Novick D, Kim S, Kaplanski G. 2013. Interleukin-18 and IL-18 binding protein. Front Immunol 4: 289.

Endo Y, Hirahara K, Iinuma T, Shinoda K, Tumes DJ, Asou HK, Matsugae N, Obata-Ninomiya K, Yamamoto H, Motohashi S, et al. 2015. The interleukin-33-p38 kinase axis confers memory $\mathrm{T}$ helper 2 cell pathogenicity in the airway. Immunity 42: 294-308.

Fang M, Li Y, Huang K, Qi S, Zhang J, Zgodzinski W, Majewski M, Wallner G, Gozdz S, Macek P, et al. 2017. IL33 promotes colon cancer cell stemness via JNK activation and macrophage recruitment. Cancer Res 77: 2735-2745.

Feuerer M, Herrero L, Cipolletta D, Naaz A, Wong J, Nayer A, Lee J, Goldfine AB, Benoist C, Shoelson S, et al. 2009. Lean, but not obese, fat is enriched for a unique population of regulatory T cells that affect metabolic parameters. Nat Med 15: 930-939.

Fock V, Mairhofer M, Otti GR, Hiden U, Spittler A, Zeisler H, Fiala C, Knofler M, Pollheimer J. 2013. Macrophagederived IL-33 is a critical factor for placental growth. J Immunol 191: 3734-3743.

Gadani SP, Walsh JT, Smirnov I, Zheng J, Kipnis J. 2015. The glia-derived alarmin IL-33 orchestrates the immune response and promotes recovery following CNS injury. Neuron 85: 703-709.

Gadani SP, Smirnov I, Smith AT, Overall CC, Kipnis J. 2017. Characterization of meningeal type 2 innate lymphocytes and their response to CNS injury. J Exp Med 214: 285 296.

Gao X, Wang X, Yang Q, Zhao X, Wen W, Li G, Lu J, Qin W, Qi Y, Xie F, et al. 2015. Tumoral expression of IL-33 inhibits tumor growth and modifies the tumor microenvironment through $\mathrm{CD} 8^{+} \mathrm{T}$ and NK cells. J Immunol 194: 438-445.

Garlanda C, Dinarello CA, Mantovani A. 2013. The interleukin-1 family: Back to the future. Immunity 39: 1003 1018.

Gudbjartsson DF, Bjornsdottir US, Halapi E, Helgadottir A, Sulem P, Jonsdottir GM, Thorleifsson G, Helgadottir H, Steinthorsdottir V, Stefansson H, et al. 2009. Sequence variants affecting eosinophil numbers associate with asth ma and myocardial infarction. Nat Genet 41: 342-347.
Halim TY, Steer CA, Matha L, Gold MJ, Martinez-Gonzalez I, McNagny KM, McKenzie AN, Takei F. 2014. Group 2 innate lymphoid cells are critical for the initiation of adaptive T helper 2 cell-mediated allergic lung inflammation. Immunity 40: 425-435.

Han JM, Wu D, Denroche HC, Yao Y, Verchere CB, Levings MK. 2015. IL-33 reverses an obesity-induced deficit in visceral adipose tissue ST2 + T regulatory cells and ameliorates adipose tissue inflammation and insulin resistance. J Immunol 194: 4777-4783.

Hardman C, Ogg G. 2016. Interleukin-33, friend and foe in type-2 immune responses. Curr Opin Immunol 42: 1624.

Hayakawa M, Yanagisawa K, Aoki S, Hayakawa H, Takezako N, Tominaga S. 2005. T-helper type 2 cell-specific expression of the ST2 gene is regulated by transcription factor GATA-3. Biochim Biophys Acta 1728: 53-64.

Hoshino K, Kashiwamura S, Kuribayashi K, Kodama T, Tsujimura T, Nakanishi K, Matsuyama T, Takeda K, Akira S. 1999. The absence of interleukin 1 receptor-related T1/ ST2 does not affect $T$ helper cell type 2 development and its effector function. J Exp Med 190: 1541-1548.

Hoyler T, Klose CS, Souabni A, Turqueti-Neves A, Pfeifer D, Rawlins EL, Voehringer D, Busslinger M, Diefenbach A. 2012. The transcription factor GATA-3 controls cell fate and maintenance of type 2 innate lymphoid cells. Immunity 37: 634-648.

Hsu CL, Neilsen CV, Bryce PJ. 2010. IL-33 is produced by mast cells and regulates IgE-dependent inflammation. PLOS ONE 5: e11944.

Hu LA, Fu Y, Zhang DN, Zhang J. 2013. Serum IL-33 as a diagnostic and prognostic marker in non-small cell lung cancer. Asian Pac J Cancer Prev 14: 2563-2566.

Jesus AA, Goldbach-Mansky R. 2014. IL-1 blockade in autoinflammatory syndromes. Annu Rev Med 65: 223-244.

Kim MS, Jeong TD, Han SB, Min WK, Kim JJ. 2015. Role of soluble ST2 as a prognostic marker in patients with acute heart failure and renal insufficiency. J Korean Med Sci 30: 569-575.

Kita H. 2011. Eosinophils: Multifaceted biological properties and roles in health and disease. Immunol Rev 242: 161 177.

Kolodin D, van Panhuys N, Li C, Magnuson AM, Cipolletta D, Miller CM, Wagers A, Germain RN, Benoist C, Mathis D. 2015. Antigen- and cytokine-driven accumulation of regulatory $\mathrm{T}$ cells in visceral adipose tissue of lean mice. Cell Metab 21: 543-557.

Komai-Koma M, Xu D, Li Y, McKenzie AN, McInnes IB, Liew FY. 2007. IL-33 is a chemoattractant for human Th2 cells. Eur J Immunol 37: 2779-2786.

Komai-Koma M, Wang E, Kurowska-Stolarska M, Li D, McSharry C, Xu D. 2016. Interleukin-33 promoting Th1 lymphocyte differentiation dependents on IL-12. Immunobiology 221: 412-417.

Kurowska-Stolarska M, Kewin P, Murphy G, Russo RC, Stolarski B, Garcia CC, Komai-Koma M, Pitman N, Li Y, Niedbala W, et al. 2008. IL-33 induces antigen-specific IL- $5^{+} \mathrm{T}$ cells and promotes allergic-induced airway inflammation independent of IL-4. J Immunol 181: 47804790. 
Kurowska-Stolarska M, Stolarski B, Kewin P, Murphy G Corrigan CJ, Ying S, Pitman N, Mirchandani A, Rana B, van Rooijen N, et al. 2009. IL-33 amplifies the polarization of alternatively activated macrophages that contribute to airway inflammation. J Immunol 183: 64696477.

Kuswanto W, Burzyn D, Panduro M, Wang KK, Jang YC, Wagers AJ, Benoist C, Mathis D. 2016. Poor repair of skeletal muscle in aging mice reflects a defect in local, interleukin-33-dependent accumulation of regulatory $\mathrm{T}$ cells. Immunity 44: 355-367.

Lee MW, Odegaard JI, Mukundan L, Qiu Y, Molofsky AB, Nussbaum JC, Yun K, Locksley RM, Chawla A. 2015. Activated type 2 innate lymphoid cells regulate beige fat biogenesis. Cell 160: 74-87.

Lee MK, Yvan-Charvet L, Masters SL, Murphy AJ. 2016. The modern interleukin-1 superfamily: Divergent roles in obesity. Semin Immunol 28: 441-449.

Lefrancais E, Roga S, Gautier V, Gonzalez-de-Peredo A, Monsarrat B, Girard JP, Cayrol C. 2012. IL-33 is processed into mature bioactive forms by neutrophil elastase and cathepsin G. Proc Natl Acad Sci 109: 1673-1678.

Li S, Neff CP, Barber K, Hong J, Luo Y, Azam T, Palmer BE, Fujita M, Garlanda C, Mantovani A, et al. 2015. Extracellular forms of IL-37 inhibit innate inflammation in vitro and in vivo but require the IL-1 family decoy receptor IL1R8. Proc Natl Acad Sci 112: 2497-2502.

Lin H, Ho AS, Haley-Vicente D, Zhang J, Bernal-Fussell J, Pace AM, Hansen D, Schweighofer K, Mize NK, Ford JE. 2001. Cloning and characterization of IL-1HY2, a novel interleukin-1 family member. J Biol Chem 276: 2059720602.

Liston A, Gray DH. 2014. Homeostatic control of regulatory T cell diversity. Nat Rev Immunol 14: 154-165.

Lohning M, Stroehmann A, Coyle AJ, Grogan JL, Lin S, Gutierrez-Ramos JC, Levinson D, Radbruch A, Kamradt T. 1998. T1/ST2 is preferentially expressed on murine Th2 cells, independent of interleukin 4 , interleukin 5 , and interleukin 10, and important for Th2 effector function. Proc Natl Acad Sci 95: 6930-6935.

Lopetuso LR, Scaldaferri F, Pizarro TT. 2012. Emerging role of the interleukin (IL)-33/ST2 axis in gut mucosal wound healing and fibrosis. Fibrogenesis Tissue Repair 5: 18.

Luo Y, Cai X, Liu S, Wang S, Nold-Petry CA, Nold MF, Bufler P, Norris D, Dinarello CA, Fujita M. 2014. Suppression of antigen-specific adaptive immunity by IL-37 via induction of tolerogenic dendritic cells. Proc Natl Acad Sci 111: 15178-15183.

Maloy KJ, Uhlig HH. 2013. ILC1 populations join the border patrol. Immunity 38: 630-632.

Martin NT, Martin MU. 2016. Interleukin 33 is a guardian of barriers and a local alarmin. Nat Immunol 17: 122-131.

Martin BN, Wang C, Zhang CJ, Kang Z, Gulen MF, Zepp JA, Zhao J, Bian G, Do JS, Min B, et al. 2016. T cell-intrinsic ASC critically promotes $\mathrm{T}_{\mathrm{H}} 17$-mediated experimental autoimmune encephalomyelitis. Nat Immunol 17: 583592.

Mitsui A, Tada Y, Takahashi T, Shibata S, Kamata M, Miyagaki T, Fujita H, Sugaya M, Kadono T, Sato S, et al. 2016. Serum IL-33 levels are increased in patients with psoriasis. Clin Exp Dermatol 41: 183-189.
Mjosberg J, Bernink J, Golebski K, Karrich JJ, Peters CP, Blom B, te Velde AA, Fokkens WJ, van Drunen CM, Spits H. 2012. The transcription factor GATA3 is essential for the function of human type 2 innate lymphoid cells. Immunity 37: 649-659.

Moffatt MF, Gut IG, Demenais F, Strachan DP, Bouzigon E, Heath S, von Mutius E, Farrall M, Lathrop M, Cookson WO, et al. 2010. A large-scale, consortium-based genomewide association study of asthma. $N$ Engl J Med 363: 1211-1221.

Molofsky AB, Van Gool F, Liang HE, Van Dyken SJ, Nussbaum JC, Lee J, Bluestone JA, Locksley RM. 2015. Interleukin-33 and interferon- $\gamma$ counter-regulate group 2 innate lymphoid cell activation during immune perturbation. Immunity 43: 161-174.

Mommsen P, Frink M, Pape HC, van Griensven M, Probst C, Gaulke R, Krettek C, Hildebrand F. 2009. Elevated systemic IL-18 and neopterin levels are associated with posttraumatic complications among patients with multiple injuries: A prospective cohort study. Injury 40: 528-534.

Monticelli LA, Sonnenberg GF, Abt MC, Alenghat T, Ziegler CG, Doering TA, Angelosanto JM, Laidlaw BJ, Yang CY, Sathaliyawala T, et al. 2011. Innate lymphoid cells promote lung-tissue homeostasis after infection with influenza virus. Nat Immunol 12: 1045-1054.

Monticelli LA, Osborne LC, Noti M, Tran SV, Zaiss DM, Artis D. 2015. IL-33 promotes an innate immune pathway of intestinal tissue protection dependent on amphiregulin-EGFR interactions. Proc Natl Acad Sci 112: $10762-$ 10767.

Moro K, Yamada T, Tanabe M, Takeuchi T, Ikawa T, Kawamoto H, Furusawa J, Ohtani M, Fujii H, Koyasu S. 2010. Innate production of $\mathrm{T}_{\mathrm{H}} 2$ cytokines by adipose tissueassociated c-Kit ${ }^{+} \mathrm{Sca}-1^{+}$lymphoid cells. Nature 463: 540-544.

Murphy AJ, Kraakman MJ, Kammoun HL, Dragoljevic D, Lee MK, Lawlor KE, Wentworth JM, Vasanthakumar A, Gerlic M, Whitehead LW, et al. 2016. IL-18 production from the NLRP1 inflammasome prevents obesity and metabolic syndrome. Cell Metab 23: 155-164.

Nabekura T, Girard JP, Lanier LL. 2015. IL-33 receptor ST2 amplifies the expansion of NK cells and enhances host defense during mouse cytomegalovirus infection. J Immunol 194: 5948-5952.

Neill DR, Wong SH, Bellosi A, Flynn RJ, Daly M, Langford TK, Bucks C, Kane CM, Fallon PG, Pannell R, et al. 2010. Nuocytes represent a new innate effector leukocyte that mediates type-2 immunity. Nature 464: 1367-1370.

Nold MF, Nold-Petry CA, Zepp JA, Palmer BE, Bufler P, Dinarello CA. 2010. IL-37 is a fundamental inhibitor of innate immunity. Nat Immunol 11: 1014-1022.

Nussbaum JC, Van Dyken SJ, von Moltke J, Cheng LE, Mohapatra A, Molofsky AB, Thornton EE, Krummel MF, Chawla A, Liang HE, et al. 2013. Type 2 innate lymphoid cells control eosinophil homeostasis. Nature 502: 245248.

Odegaard JI, Lee MW, Sogawa Y, Bertholet AM, Locksley RM, Weinberg DE, Kirichok Y, Deo RC, Chawla A. 2016. Perinatal licensing of thermogenesis by IL-33 and ST2. Cell 166: 841-854.

Ohne Y, Silver JS, Thompson-Snipes L, Collet MA, Blanck JP, Cantarel BL, Copenhaver AM, Humbles AA, Liu YJ. 
2016. IL-1 is a critical regulator of group 2 innate lymphoid cell function and plasticity. Nat Immunol 17: 646655.

O’Neill L. 2000. The Toll/interleukin-1 receptor domain: A molecular switch for inflammation and host defence. Biochem Soc Trans 28: 557-563.

O'Neill LA, Greene C. 1998. Signal transduction pathways activated by the IL-1 receptor family: Ancient signaling machinery in mammals, insects, and plants. J Leukoc Biol 63: 650-657.

Perrier S, Caldefie-Chezet F, Vasson MP. 2009. IL-1 family in breast cancer: Potential interplay with leptin and other adipocytokines. FEBS Lett 583: 259-265.

Pichery M, Mirey E, Mercier P, Lefrancais E, Dujardin A, Ortega N, Girard JP. 2012. Endogenous IL-33 is highly expressed in mouse epithelial barrier tissues, lymphoid organs, brain, embryos, and inflamed tissues: In situ analysis using a novel Il-33-LacZ gene trap reporter strain. J Immunol 188: 3488-3495.

Pollock AS, Turck J, Lovett DH. 2003. The prodomain of interleukin $1 \alpha$ interacts with elements of the RNA processing apparatus and induces apoptosis in malignant cells. FASEB J 17: 203-213.

Pope SM, Brandt EB, Mishra A, Hogan SP, Zimmermann N, Matthaei KI, Foster PS, Rothenberg ME. 2001. IL-13 induces eosinophil recruitment into the lung by an IL-5and eotaxin-dependent mechanism. J Allergy Clin Immunol 108: 594-601.

Qian L, Yuanshao L, Wensi H, Yulei Z, Xiaoli C, Brian W, Wanli Z, Zhengyi C, Jie X, Wenhui Z, et al. 2016. Serum IL-33 is a novel diagnostic and prognostic biomarker in acute ischemic stroke. Aging Dis 7: 614-622.

Rider P, Carmi Y, Guttman O, Braiman A, Cohen I, Voronov E, White MR, Dinarello CA, Apte RN. 2011. IL-1 $\alpha$ and IL-1 $\beta$ recruit different myeloid cells and promote different stages of sterile inflammation. J Immunol 187: 48354843.

Rosser EC, Oleinika K, Tonon S, Doyle R, Bosma A, Carter NA, Harris KA, Jones SA, Klein N, Mauri C. 2014. Regulatory $\mathrm{B}$ cells are induced by gut microbiota-driven interleukin- $1 \beta$ and interleukin-6 production. Nat Med 20: 1334-1339.

Sattler S, Ling GS, Xu D, Hussaarts L, Romaine A, Zhao H, Fossati-Jimack L, Malik T, Cook HT, Botto M, et al. 2014. IL-10-producing regulatory $\mathrm{B}$ cells induced by IL-33 $\left(\right.$ Breg $^{\text {IL-33) }}$ effectively attenuate mucosal inflammatory responses in the gut. J Autoimmun 50: 107-122.

Schiering C, Krausgruber T, Chomka A, Frohlich A, Adelmann K, Wohlfert EA, Pott J, Griseri T, Bollrath J, Hegazy AN, et al. 2014. The alarmin IL-33 promotes regulatory T-cell function in the intestine. Nature 513: 564-568.

Schmitz J, Owyang A, Oldham E, Song Y, Murphy E, McClanahan TK, Zurawski G, Moshrefi M, Qin J, Li X, et al. 2005. IL-33, an interleukin-1-like cytokine that signals via the IL-1 receptor-related protein ST2 and induces T helper type 2-associated cytokines. Immunity 23: 479490.

Sharma S, Kulk N, Nold MF, Graf R, Kim SH, Reinhardt D, Dinarello CA, Bufler P. 2008. The IL-1 family member 7b translocates to the nucleus and down-regulates proinflammatory cytokines. J Immunol 180: 5477-5482.
Sims JE, Smith DE. 2010. The IL-1 family: Regulators of immunity. Nat Rev Immunol 10: 89-102.

Stolarski B, Kurowska-Stolarska M, Kewin P, Xu D, Liew FY. 2010. IL-33 exacerbates eosinophil-mediated airway inflammation. J Immunol 185: 3472-3480.

Sutton CE, Lalor SJ, Sweeney CM, Brereton CF, Lavelle EC, Mills KH. 2009. Interleukin- 1 and IL-23 induce innate IL17 production from $\gamma \delta \mathrm{T}$ cells, amplifying Th17 responses and autoimmunity. Immunity 31: 331-341.

Talabot-Ayer D, Lamacchia C, Gabay C, Palmer G. 2009. Interleukin-33 is biologically active independently of caspase-1 cleavage. J Biol Chem 284: 19420-19426.

Teh PP, Vasanthakumar A, Kallies A. 2015. Development and function of effector regulatory T cells. Prog Mol Biol Transl Sci 136: 155-174.

Tidball JG, Villalta SA. 2010. Regulatory interactions between muscle and the immune system during muscle regeneration. Am J Physiol Regul Integr Comp Physiol 298: R1173-R1187.

Tominaga S. 1989. A putative protein of a growth specific cDNA from BALB/c-3T3 cells is highly similar to the extracellular portion of mouse interleukin 1 receptor. FEBS Lett 258: 301-304.

Towne JE, Renshaw BR, Douangpanya J, Lipsky BP, Shen M, Gabel CA, Sims JE. 2011. Interleukin-36 (IL-36) ligands require processing for full agonist (IL-36 $\alpha$, IL-36 $\beta$, and IL-36 $\gamma$ ) or antagonist (IL-36Ra) activity. J Biol Chem 286: 42594-42602.

van de Veerdonk FL, Netea MG. 2013. New insights in the immunobiology of IL-1 family members. Front Immunol 4: 167.

Vasanthakumar A, Moro K, Xin A, Liao Y, Gloury R, Kawamoto S, Fagarasan S, Mielke LA, Afshar-Sterle S, Masters SL, et al. 2015. The transcriptional regulators IRF4, BATF and IL-33 orchestrate development and maintenance of adipose tissue-resident regulatory $\mathrm{T}$ cells. Nat Immunol 16: $276-285$.

Vigne S, Palmer G, Lamacchia C, Martin P, Talabot-Ayer D, Rodriguez E, Ronchi F, Sallusto F, Dinh H, Sims JE, et al. 2011. IL-36R ligands are potent regulators of dendritic and T cells. Blood 118: 5813-5823.

Vigne S, Palmer G, Martin P, Lamacchia C, Strebel D, Rodriguez E, Olleros ML, Vesin D, Garcia I, Ronchi F, et al. 2012. IL-36 signaling amplifies Th1 responses by enhancing proliferation and Th1 polarization of naïve $\mathrm{CD}^{+} \mathrm{T}$ cells. Blood 120: 3478-3487.

Villaret A, Galitzky J, Decaunes P, Esteve D, Marques MA, Sengenes C, Chiotasso P, Tchkonia T, Lafontan M, Kirkland JL, et al. 2010. Adipose tissue endothelial cells from obese human subjects: Differences among depots in angiogenic, metabolic, and inflammatory gene expression and cellular senescence. Diabetes 59: 2755-2763.

Voronov E, Carmi Y, Apte RN. 2014. The role IL-1 in tumormediated angiogenesis. Front Physiol 5: 114.

Wang S, Ding L, Liu SS, Wang C, Leng RX, Chen GM, Fan YG, Pan HF, Ye DQ. 2012. IL-33: A potential therapeutic target in autoimmune diseases. J Investig Med 60: 11511156.

Wang X, Zhao X, Feng C, Weinstein A, Xia R, Wen W, Lv Q, Zuo S, Tang P, Yang X, et al. 2015. IL-36 $\gamma$ transforms the tumor microenvironment and promotes type 1 lympho- 
cyte-mediated antitumor immune responses. Cancer Cell 28: $296-306$

Wang C, Chen Z, Bu X, Han Y, Shan S, Ren T, Song W. 2016a. IL-33 signaling fuels outgrowth and metastasis of human lung cancer. Biochem Biophys Res Commun 479: 461-468.

Wang DW, Dong N, Wu Y, Zhu XM, Wang CT, Yao YM. 2016b. Interleukin-37 enhances the suppressive activity of naturally occurring $\mathrm{CD} 4{ }^{+} \mathrm{CD} 25^{+}$regulatory $\mathrm{T}$ cells. Sci Rep 6: 38955.

Wasmer MH, Krebs P. 2016. The role of IL-33-dependent inflammation in the tumor microenvironment. Front Immunol 7: 682.

Wensveen FM, Valentic S, Sestan M, Turk Wensveen T, Polic B. 2015. The "big bang" in obese fat: Events initiating obesity-induced adipose tissue inflammation. Eur J Immunol 45: 2446-2456.

Wesa AK, Galy A. 2001. IL-1 $\beta$ induces dendritic cells to produce IL-12. Int Immunol 13: 1053-1061.

Xi H, Katschke KJ Jr., Li Y, Truong T, Lee WP, Diehl L, Rangell L, Tao J, Arceo R, Eastham-Anderson J, et al. 2016. IL-33 amplifies an innate immune response in the degenerating retina. J Exp Med 213: 189-207.
Yamaguchi Y, Hayashi Y, Sugama Y, Miura Y, Kasahara T, Kitamura S, Torisu M, Mita S, Tominaga A, Takatsu K. 1988. Highly purified murine interleukin 5 (IL-5) stimulates eosinophil function and prolongs in vitro survival. IL-5 as an eosinophil chemotactic factor. J Exp Med 167: 1737-1742.

Yanagisawa K, Takagi T, Tsukamoto T, Tetsuka T, Tominaga S. 1993. Presence of a novel primary response gene ST2L encoding a product highly similar to the interleukin 1 receptor type 1. FEBS Lett 318: 83-87.

Yang Q, Li G, Zhu Y, Liu L, Chen E, Turnquist H, Zhang X, Finn OJ, Chen X, Lu B. 2011. IL-33 synergizes with TCR and IL-12 signaling to promote the effector function of $\mathrm{CD}^{+} \mathrm{T}$ cells. Eur J Immunol 41: 3351-3360.

Yasuoka S, Kawanokuchi J, Parajuli B, Jin S, Doi Y, Noda M, Sonobe Y, Takeuchi H, Mizuno T, Suzumura A. 2011 Production and functions of IL-33 in the central nervous system. Brain Res 1385: 8-17.

Yoshimoto T, Takeda K, Tanaka T, Ohkusu K, Kashiwamura S, Okamura H, Akira S, Nakanishi K. 1998. IL-12 upregulates IL-18 receptor expression on T cells, Th1 cells, and B cells: Synergism with IL-18 for IFN- $\gamma$ production. J Immunol 161: 3400-3407. 


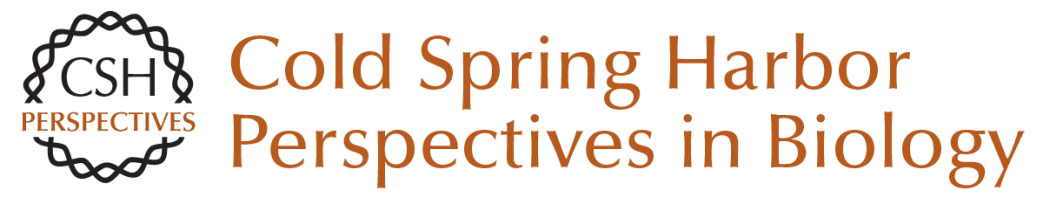

\title{
Interleukin (IL)-33 and the IL-1 Family of Cytokines--Regulators of Inflammation and Tissue Homeostasis
}

\author{
Ajithkumar Vasanthakumar and Axel Kallies
}

Cold Spring Harb Perspect Biol 2019; doi: 10.1101/cshperspect.a028506 originally published online November 3, 2017

\section{Subject Collection Cytokines}

Interleukin (IL)-33 and the IL-1 Family of Cytokines

--Regulators of Inflammation and Tissue

Homeostasis

Ajithkumar Vasanthakumar and Axel Kallies

Targeting IL-10 Family Cytokines for the Treatment of Human Diseases

Xiaoting Wang, Kit Wong, Wenjun Ouyang, et al.

Cytokine-Mediated Regulation of CD8 T-Cell Responses During Acute and Chronic Viral Infection

Masao Hashimoto, Se Jin Im, Koichi Araki, et al.

Cytokines in Cancer Immunotherapy

Thomas A. Waldmann

The Tumor Necrosis Factor Family: Family Conventions and Private Idiosyncrasies David Wallach

The Interferon (IFN) Class of Cytokines and the IFN Regulatory Factor (IRF) Transcription Factor Family

Hideo Negishi, Tadatsugu Taniguchi and Hideyuki Yanai
Interferon $\gamma$ and Its Important Roles in Promoting and Inhibiting Spontaneous and Therapeutic Cancer Immunity

Elise Alspach, Danielle M. Lussier and Robert D. Schreiber

Inflammasome-Dependent Cytokines at the Crossroads of Health and Autoinflammatory Disease

Hanne Van Gorp, Nina Van Opdenbosch and Mohamed Lamkanfi

Innate Lymphoid Cells (ILCs): Cytokine Hubs

Regulating Immunity and Tissue Homeostasis Maho Nagasawa, Hergen Spits and Xavier Romero Ros

T Helper Cell Differentiation, Heterogeneity, and

Plasticity Jinfang Zhu

Development, Diversity, and Function of Dendritic

Cells in Mouse and Human

David A. Anderson III, Kenneth M. Murphy and Carlos G. Briseño

Cytokines and Long Noncoding RNAs Susan Carpenter and Katherine A. Fitzgerald

For additional articles in this collection, see http://cshperspectives.cshlp.org/cgi/collection/

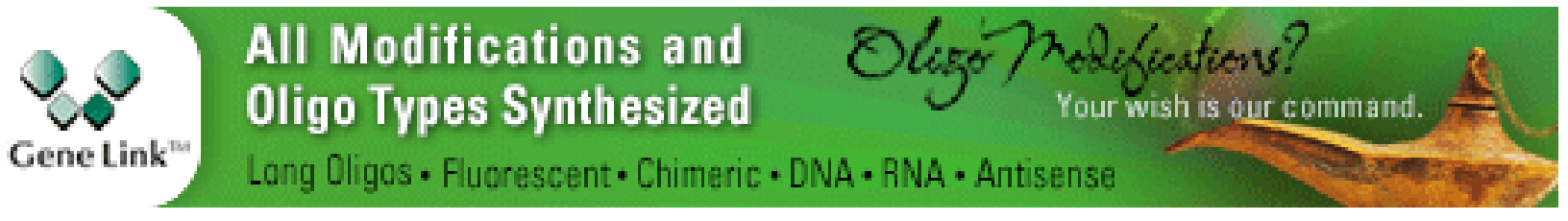


Role of the $\beta$ Common $(\beta \mathrm{c})$ Family of Cytokines in Health and Disease

Timothy R. Hercus, Winnie L. T. Kan, Sophie E. Broughton, et al.

Interleukin (IL)-12 and IL-23 and Their Conflicting Roles in Cancer Juming Yan, Mark J. Smyth and Michele W.L. Teng
Negative Regulation of Cytokine Signaling in Immunity

Akihiko Yoshimura, Minako Ito, Shunsuke Chikuma, et al.

Cancer Inflammation and Cytokines

Maria Rosaria Galdiero, Gianni Marone and Alberto Mantovani

For additional articles in this collection, see http://cshperspectives.cshlp.org/cgi/collection/

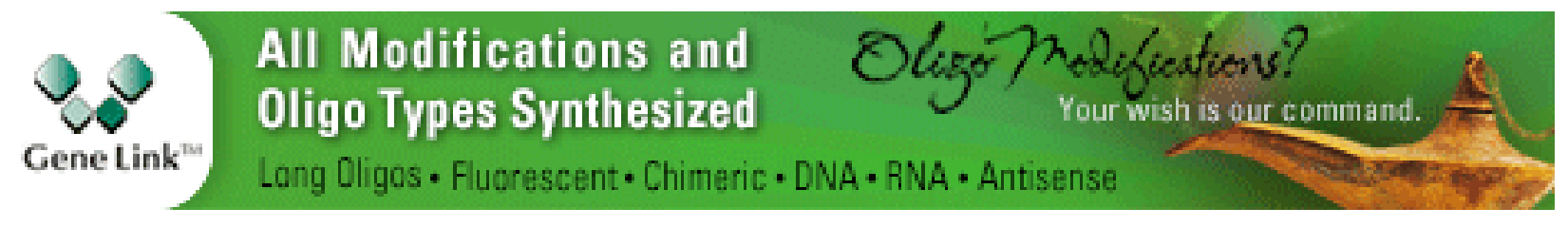

Copyright @ 2019 Cold Spring Harbor Laboratory Press; all rights reserved 